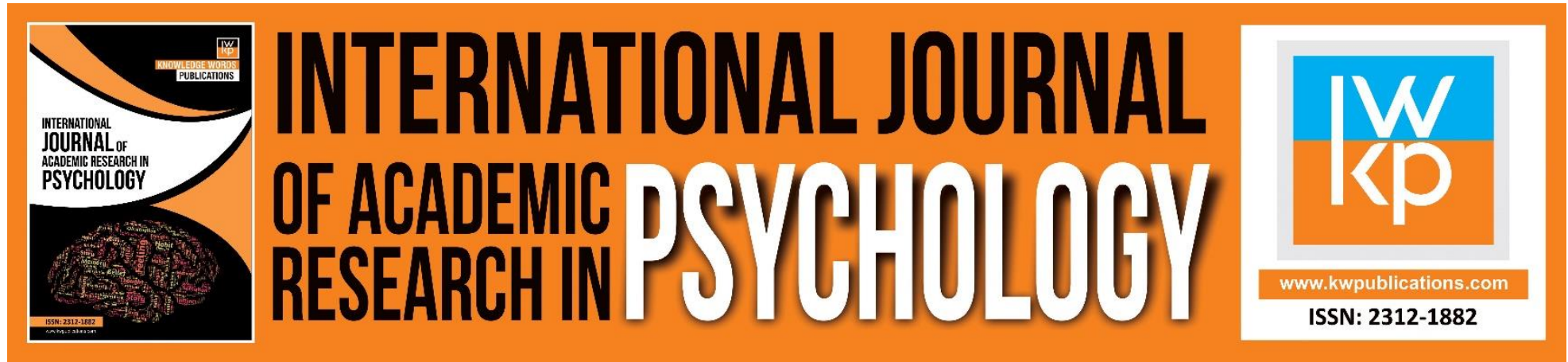

\title{
Parents' Perception of the Causes and Effects of Child Abuse in Ondo State, Nigeria
}

Bada, Steve Olusegun

To Link this Article: http://dx.doi.org/10.46886/IJARP/v2-i1/1903

DOI: 10.46886/IJARP/v2-i1/1903

Received: 04 June 2015, Revised: 10 July 2015, Accepted: 13 August 2015

Published Online: 27 August 2015

In-Text Citation: (Bada, 2015)

To Cite this Article: Bada, S. O. (2015) Parents' Perception of the Causes and Effects of Child Abuse in Ondo State, Nigeria. International Journal of Academic Research in Psychology. 2(1), 53-62.

\section{Copyright: (C) 2015 The Author(s)}

Published by Knowledge Words Publications (www.kwpublications.com)

This article is published under the Creative Commons Attribution (CC BY 4.0) license. Anyone may reproduce, distribute, translate and create derivative works of this article (for both commercial and non-commercial purposes), subject to full attribution to the original publication and authors. The full terms of this license may be seen

at: http://creativecommons.org/licences/by/4.0/legalcode

\section{Vol. 2, No. 1, 2015, Pg. 53 - 62}

Full Terms \& Conditions of access and use can be found at https://kwpublications.com/pages/detail/publication-ethics 


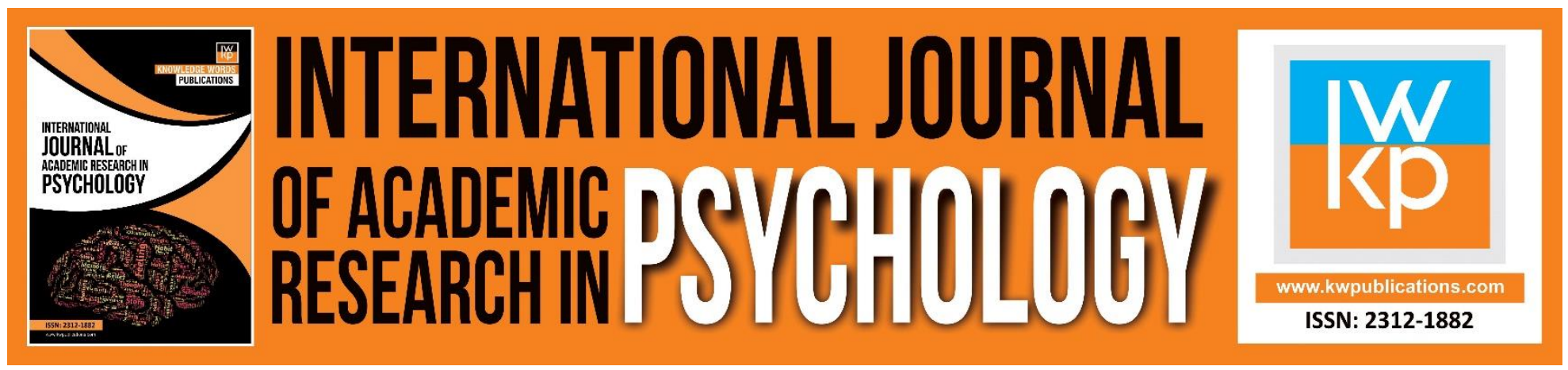

\title{
Parents' Perception of the Causes and Effects of Child Abuse in Ondo State, Nigeria
}

\author{
Bada, Steve Olusegun PhD \\ Department of Psychology, Federal University of Education, Kano \\ Email: bdolusegun@gmail.com
}

\begin{abstract}
The study examined the causes and effects of child abuse as perceived by parents in Ondo State. The population for the study comprised every parent within the state. From the population, 200 respondents were sampled using purposive sampling technique. The samples were further stratified on the basis of gender, educational status and residence. Data were collected using a researcher designed questionnaire titled Child Abuse Questionnaire (CAQ). The instrument was found valid and reliable with reliability coefficient of 0.79 . Data collected were analyzed using percentages and t-test. Based on the findings, parents identified poverty, marital crises, and illiteracy as the main causes of child abuse. Among the identified effects of child abuse are school dropout, poor academic performance, sexual assaults and emotional breakdown. However, significant differences were found in parents' expressed causes of child abuse on the basis of educational status and residence but parents' expressed causes of child abuse did not significantly differ on the basis of gender. On the other hand parents' expressed effects of child abuse also differed, significantly on the basis of educational status and residence but not on gender. It was therefore concluded that parents' perceptions of causes and effects of child abuse greatly depended on their educational status and residence. Based on these findings, it was recommended that policy makers should come up with more enlighten programmes on effects of child abuse for parents in rural and urban areas.
\end{abstract}

Keywords: Child, Child Abuse, Educated, Illiterate Parents, Rural and Urban Residence.

\section{Introduction}

Around the world, children are identified as asset. Parents, government and nongovernmental bodies work towards making their living free of cultural and economic huddles. From the time of its establishment, the United Nations Organization has been showing interest in children and trying to solve all forms of problems associating with their life. The need to make children living free of problems, national and international bodies do establishes agencies that are solely concerned with solving children problems. For example at the end of 1946, the United Nation Organization established the International Children Emergency fund (UNICEF) to cater for children in war turned 
areas. However, the intensified social crisis around the world brought about enlargement and permanency of the scope of UNICEF. Since 1953, UNICEF has been providing children throughout the world with food, clothing and medical care and has been trying to ease out children that are hooked by cultural practices that subject them to different abuse.

Child abuse is the physical, sexual or emotional mistreatment of children. It is all form of social and cultural practices that subject children to humiliation, and emotional breakdown. Because of economic crises that now pervade the world, children now face high incidence of abuse (Welesh, 2000). According to the National Committee to Prevent Child Abuse, in 1997, neglect represented $54 \%$ of confirmed cases of child abuse, physical abuse $22 \%$, sexual abuse $8 \%$ emotional maltreatment $8 \%$ and other forms of maltreatment $12 \%$. Child abuse is not a good experience. It is one experience that can hamper child's life biologically, emotionally, psychologically, and educationally. Yet despite the international outcry on the evils of child abuse much has not been achieved at eradicating it. One reason for this is what Welesh (2000) called inadequate information and understanding of the acts. Welesh (2000) claimed that little is known about what child care stakeholders perceived as chid labour. Many even believe that child abuse is not as serious as the world child protection organizations claimed it is. Because child abuse is relatively perpetrated in cultural settings, human attitude towards it and people's perceptions about its causes and effects can vary.

Adeojo (2008) writes that different social jurisdiction have developed their own definitions of what constitutes child abuse for the purposes of removing a child from his/her family and/or prosecuting a criminal charge. According to the journal of child abuse and neglect, child abuse is 'any recent act or failure to act on the part of a parent or caretaker which results in death, serious physical or sexual abuse or exploitation, an act or failure to act which presents and imminent risk of serious harm to a child.

Internationally, child abuse is seen as all form of injustice that enslaves a child or takes advantage of children's naïve nature or ignorance to enrich socially and economically the adult folk. Child abuse is when the life of the child is in danger or when the maltreatment can result in fatality. Every child around the world is entitled to good education. The education is expected to be free, compulsory and universal. It is in furtherance of this that national and international governments are encouraged to provide human and non-human facilities that will make education available to all irrespective of the gender, the ethnic, residence and religion of the child (Little, 1997). Elebu (1990) is of the opinion that the first care that a child can receive from his/her parent is to be educated and be socialized to become relevant in his/her society. When a child is denied this first opportunity, his chance of getting it remedied when grown up is almost zero. One thing about education as the first right of a child is that when a child is not educated he can become vulnerable to other future life of maltreatment.

In Nigeria, there are laws that make it a punishable offence for parents who refuse to send their children to school to receive basic education. Such parent is fined and subsequently sentenced to imprisonment terms depending on the gravity and severalty of the offence (FGN, 2006). In 1990, delegates from 155 countries as well as representatives from 150 organizations had agreed at the World Conference on Education for All (EFA) in Jomitien, Thailand to provide basic education to all, irrespective of social background, by the year 2005 (later shifted to 2015); particularly to girls, children in difficult circumstances and those belonging to ethnic minorities. Nations agreed to provide easy access to and complete free and compulsory primary education (Kisseka, 1981). 
Child abuse is a serious problem that can render a child to develop haphazardly, emotionally and academically. International organizations have expressed concerns about child abuse and have proved that abused children lack the potentials to contribute to the development of his or her society. The results of being abused as a child vary according to the severity of the abuse and the surrounding environment of the child. If the social environment of the family or school is nurturing and supportive, the child will probably have a better outcome. Child abuse is itself a disservice to child's upbringing. Parents are expected to show love and care towards their children and they are expected to provide enabling environment that will aid their children to develop self-confidence.

Ebigbo (1989) opines that physical abuse may result in difficulty establishing intimate personal relationships, difficulty in adulthood it physical closeness, touching, intimacy or trust and high levels of anxiety, depression, substance abuse, medical illness or problems at school or work. The inadequacy of information on the causes and effects of child abuse around the world justify the need for this study. Many are yet to be done in understanding what parents in particular expressed as causes and effects of child abuse in Ondo State. Thus, this study was carried out in order to find out parents' perceptions about causes and effects of child abuse on the bases of gender, residence and educational status.

\section{Purpose of the Study}

The purpose of this study is to find out parents' expressed causes and effect of child abuse in Ondo State. Specifically, the study find out:

1. whether parent's expressed causes of child abuse vary on the basis of gender

2. whether parents' expressed causes of child abuse vary on the basis of residence.

3. whether parents' expressed causes of child abuse vary on the basis of educational level.

4. whether parents' expressed effects of child abuse vary on the basis of gender.

5. whether parents' expressed effects of child abuse vary on the basis of residence.

6. whether parents' expressed effects of child abuse vary on the basis of educational level.

\section{Research Questions}

For the purpose of this study, the following research questions were raised and some answered or transformed to hypotheses and tested in this study.

1. Do parents expressed causes of child abuse vary on the basis of gender?

2. Do parents expressed causes of child abuse vary on the basis of residence?

3. Do parent's expressed causes of child abuse vary on the basis educational level?

4. Do parents' expressed effects of child abuse vary on the basis of gender?

5. Do parents' expressed effects of child abuse vary on the basis of residence?

6. Do parents' expressed effects of child abuse vary on the basis of educational level?

7.

\section{Research Hypotheses}

The following research null hypotheses were raised and tested in the study.

$\mathrm{H}_{01}$ : Parents' expressed causes of child abuse does not significantly vary on the basis of gender in Ondo state.

$\mathrm{H}_{\mathrm{O} 2}$ : Parents' expressed causes of child abuse does not significantly vary on the basis of residence in Ondo state. 
INTERNATIONAL JOURNAL OF ACADEMIC RESEARCH IN PSYCHOLOGY

Vol. 2, No. 1, 2015, E-ISSN: 2312-1882 @ 2015 KWP

Ho3: Parents' expressed causes of child abuse does not significantly vary on the basis of educational level in Ondo state.

Ho4: Parents' expressed effect of child abuse does not significantly vary on the basis of gender in Ondo state.

Ho5: Parents' expressed effect of child abuse does not significantly vary on the basis of residence in Ondo state.

$\mathrm{H}_{\mathrm{O6}}$ : Parents' expressed effect of child abuse does not significantly vary on the basis of educational level in Ondo state.

\section{Scope of the Study}

The study is limited to Ondo State. There are eighteen local governments in the state. However, samples were drawn from only five (5) Local Government Areas comprising rural and urban settlements of the LGA.

\section{Methodology}

The study employed descriptive research survey method. The use of the descriptive research survey method allowed the researcher to collect relevant data relating to child abuse from relatively large sample representing parents in Ondo State. The population for the study consisted of every parents in Ondo state, Nigeria comprising two urban and two rural areas settlements in the LGAs selected. From the population, purposive sampling technique was used to sample a total of 200 parents across the four settlements. The sampled parents were further stratified on the basis of gender, educational status, and residence. This sampling technique gave the research adequate coverage of the studied population.

The instrument used for data collection was a research-made questionnaire titled Child Abuse Questionnaire (CAQ). The instrument has three sections. Section ' $A$ ' elicited information on respondents' biographical data such as gender, educational status and residence. Respondents' responses to items in this section were used in stratifying the sample into the referred strata. The Section ' $B$ ' has fifteen (15) items in each of the two parts. Respondents were asked to identify specific causes of child abuse in the part one and specific effects of child abuse in the part two. The Section ' $C$ ' has fifteen (15) items eliciting respondent's perceived consequences of child abuse. Each of the items has response options ranging from Strongly Agree (SA), Agree (A), Disagree (D) and Strongly Disagree (SD).

The instrument was validated using face and content validity approaches. The corrections suggested by the experts were effected on the final draft of the instrument before it was administered on the respondents. The instrument was tested for reliability using test-re-test approach. Using this procedure, the researcher administered the instrument twice at an interval of three weeks on sub-sample of the study. The two sets of scores derived from the two-time administration of the instrument were correlated using Pearson Moment Correlation Coefficient statistic ( $r$ ). Through this process, a reliability coefficient of 0.79 was derived and this was adjudged as good enough in making the instrument reliable for the study. Data collected were analyzed using descriptive statistic and t-test analysis. 
INTERNATIONAL JOURNAL OF ACADEMIC RESEARCH IN PSYCHOLOGY

Vol. 2, No. 1, 2015, E-ISSN: 2312-1882 @ 2015 KWP

Results

Table 1: Description of the sampled respondents on the basis of demographical variables

\begin{tabular}{llllllllllll}
\hline \multicolumn{1}{c}{ Gender } & \multicolumn{1}{c}{ Residence } & \multicolumn{3}{c}{ Educational Status } \\
\hline $\mathrm{M}$ & & $\mathrm{F}$ & & \multicolumn{2}{c}{ Rural } & \multicolumn{2}{c}{ Urban } & \multicolumn{2}{c}{ Literate } & Illiterate \\
$\mathrm{n}$ & $\%$ & $\mathrm{n}$ & $\%$ & $\mathrm{~N}$ & $\%$ & $\mathrm{n}$ & $\%$ & $\mathrm{n}$ & $\%$ & $\mathrm{n}$ & $\%$ \\
\hline 111 & 55.5 & 44.5 & 100 & 50 & 100 & 50 & 100 & 105 & 52.5 & 95 & 47.5 \\
\hline
\end{tabular}

As shown on Table 1, out of the sampled respondents, 111(55.5) were male parents and 89 (44.5) were female parents. Also, 100 (50\%) were sampled from rural settlements and another 100 $(50 \%)$ were sampled from urban settlement. Out of the sampled parents, 105(52.5\%) were educated and the remaining 95(47.5\%) were illiterate.

\section{Hypotheses Testing}

$H_{01}$ : Parents' expressed causes of child labour do not significantly vary on the basis of gender in Ondo state.

Table 2: T-test of Difference in Parents' Expressed Causes of Child Labour

\begin{tabular}{|c|c|c|c|c|c|c|}
\hline Variables & $\mathrm{n}$ & $x$ & SD & $d f$ & t-cal value & t- table value \\
\hline \multirow[t]{2}{*}{ Male } & 111 & 50.69 & 14.63 & & & \\
\hline & & & & 198 & 1.57 & 1.96 \\
\hline Female & 89 & 50.73 & 14.54 & & & \\
\hline
\end{tabular}

As indicated on Table 2, the t-test calculated value (1.57) is less than the t-test table value (1.96) thus, hypothesis one was accepted and it was concluded that parents' expressed causes of child labour does not significantly vary on the basis of gender.

Ho2: Parents' expressed causes of child labour do not significantly vary on the basis of residence in Ondo state.

Table 3: T-test of Difference in Parents' Expressed Causes of Child Labour

\begin{tabular}{lllllll}
\hline Variables & $\mathrm{n}$ & $\mathrm{X}$ & $\mathrm{SD}$ & $\mathrm{df}$ & $\mathrm{t}$ - cal value & $\mathrm{t}$ - table value \\
\hline Rural & 100 & 36.27 & 12.11 & & & \\
& & & & 198 & 2.42 & 1.96 \\
Urban & 100 & 52.55 & 15.35 & & & \\
\hline
\end{tabular}

$$
p>0.05
$$

On Table 3 the t-tests calculated value, (2.42) is higher than the t-test table value (1.96) thus the hypothesis two was rejected and it was concluded that what parents in rural and urban center perceived as causes of child labour significantly differ.

Hо3: Parents' expressed causes of child labour do not significantly vary on the basis of educational status in Ondo state. 
INTERNATIONAL JOURNAL OF ACADEMIC RESEARCH IN PSYCHOLOGY

Vol. 2, No. 1, 2015, E-ISSN: 2312-1882 @ 2015 KWP

Table 4: T-test difference in Parents' Expressed Causes of Child Labour

\begin{tabular}{lllllll}
\hline Variables & $\mathrm{n}$ & $\mathrm{X}$ & $\mathrm{SD}$ & $\mathrm{df}$ & $\mathrm{t}$ - cal value & t-table value \\
\hline Literate & 105 & 45.27 & 11.26 & & & \\
& & & & 198 & 2.03 & 1.96 \\
Illiterate & 94 & 33.33 & 13.21 & & & \\
\hline
\end{tabular}

$p>0.05$

On Table 4, the t-test table value (1.96) was less than the t-test calculated value (2.03) thus. Hypothesis three was rejected and it was concluded that significant difference existed in literate and illiterates parents' expressed caused of child labour in Ondo State.

Ho4: Parents' expressed effects of child labour do not significantly vary on the basis of gender in Ondo state

Table 5: T-test of difference in Parents' Expressed Effects of Child Labour

\begin{tabular}{lllllll}
\hline Variables & $\mathrm{n}$ & $\mathrm{X}$ & $\mathrm{SD}$ & $\mathrm{df}$ & $\mathrm{t}$ - cal value & $\mathrm{t}$ - table value \\
\hline Male & 111 & 43.69 & 12.52 & & & \\
Female & 89 & 61.37 & 14.41 & & 198 & 2.00 \\
\hline
\end{tabular}

$p>0.05$

Data on Table 5 showed that the t-test calculated value is higher than the t-test table value thus, hypothesis four was rejected and it was concluded that parents' expressed effects of child labour significantly varied on the basis of gender.

Ho5: Parents' expressed effect of child labour do not significantly vary on the basis of residence in Ondo state.

Table 6: T-test of Difference in Parents' Expressed Effects of Child Labour

\begin{tabular}{lllllll}
\hline Variables & $\mathrm{n}$ & $\mathrm{X}$ & $\mathrm{SD}$ & $\mathrm{df}$ & $\mathrm{t}$-cal value & t-table value \\
\hline Rural & 100 & 55.10 & 13.15 & & & \\
Urban & 100 & 47.22 & 14.20 & & & \\
\hline & $\mathrm{p}>0.05$ & & & & & \\
\end{tabular}

On Table 6, the t-test calculated value, (2.11) is higher than the t-test table value (1.96). Thus, hypothesis five was rejected and it was concluded that parents in rural and urban centers have different perceptions on the effects of child labour in Ondo state.

Ho6: $\quad$ Parents' expressed effects of child labour do not significantly vary on the basis of educational status in Ondo state. 
INTERNATIONAL JOURNAL OF ACADEMIC RESEARCH IN PSYCHOLOGY

Vol. 2, No. 1, 2015, E-ISSN: 2312-1882 @ 2015 KWP

Table 7: T-test of Difference in Parents' Expressed Effects of Child Labour

\begin{tabular}{lllllll}
\hline Variables & $\mathrm{n}$ & $\mathrm{X}$ & $\mathrm{SD}$ & $\mathrm{df}$ & $\mathrm{t}$ - cal value & t- table value \\
\hline Literate & 105 & 54.43 & 14.34 & & & \\
& & & & 198 & 2.41 & 1.96 \\
Illiterate & 94 & 65.22 & 13.40 & & & \\
\hline
\end{tabular}

$p>0.05$

On Table 7, the t-test table value (1.96) was less than the t-test calculated value (2.41). Thus, hypothesis six was rejected and it was concluded that significant difference existed in literate and illiterate parents' expressed effects of child labour in Ondo State.

\section{Discussion}

Child abuse is an international crisis. It is one major social problem that affects family life and subsequently, national development. Around the world, in the year 2003, 906 children were estimated to be victims of child abuse or neglect (Berlin, 2004). Child abuse is a serious vice that now affects child development across the world. It is one evil that nations have been striving to correct.

There are different types of child abuse, however, in this study, the researcher focused on physical abuse, sexual abuse, emotional abuse and neglect. On this base, the researcher find out what factors contribute to the perpetration of these series of abuse on children and the consequences the abuse may have on the children. Thus, the study found out that one major cause of child abuse is lack of parental knowledge on what constitute child abuse. It was found out that many parents do not really know what act of theirs result in child abuse. Because of parenting style often adopted by many parents and because many parents believe they have the right of discipline their children through any means, they hardly believe that their action constitute child abuse. Thus, a parent that beat his child at home because of child disobedience or the one that give the child a duty as punishment may not really know when such punishment get out of hand since such parent may have preoccupied his/her mind that as a parent he/she has the full unchallengeable right to discipline his/her child.

The findings was buttressed by Adeojo (2008) who points out that parents are the major child abuser because parents often erroneously believe as parents they have unlimited duty of discipline their children. Neglect was found among the major common type of child abuse perpetrated by parents on their children. Neglect is a failure to provide for the child's basic needs. The types of neglect are physical neglect, educational neglect and emotional neglect. Physical neglect is when a parent failed to provide for a child's physical needs which may include inadequate provision of food, housing or clothing, lack of behavioural supervision, expulsion from the home or refusal to allow a runaway to return home. Others are abandonment, denial of medical care and inadequate hygiene. Looking at these series of mentioned types of physical child abuse, one will see that base on ignorance or gross inadequate knowledge of what constitute child abuse, a parent can inflict any of the abuse on the child without knowing he is abusing the child.

On the other hand, some hypotheses were tested to find out whether parents perception on the causes of child abuse will differ and the following were found: Male and female parents' perceived causes of child labour in Ondo State did not differ significantly. However, significant difference was found in parents' perceived causes of child labour on the basis of residence. Also, 
literate and illiterate parents' perceived causes of child labour significantly differed. However, sampled parents' perceived causes of child labour did not significantly differ on the basis of religion.

The implications of the findings through the tested hypotheses are parents residence can influence what they perceive as causes and consequences of child abuse. Thus, a parent in rural area may have a different opinion from those in urban center. There is no doubt that human's knowledge on social issue can depend on where the parent live (Benjamin, 2000). Human residence can go a long way to determine the volume and quality of social information a parent can have access to and such information can form the attitude of the parent towards child abuse.

One main effect of child abuse as identified in this study is breakdown in child's emotional development. A child exposed to series of child abuse can grow up to lose self-confidence and may grow up to have emotional disorder. This finding was in line with that of Tentra (2009) findings in a research he conducted in Boston. Tentra found out that children that grew up and abused were found to be emotionally weak than those that grew in loving and abuse-free environment.

\section{Conclusion}

Generally, child abuse is an international enemy of child development. Around the world, child abuse is said to account for child mortality, and derailment in child's educational progress. Importantly, it was found that what male and female parents perceived as effects of child labour significantly differed. Parents tend to abuse their children or ward because of stress the parents themselves face. Such stress may emanate from parental work experiences, financial incapability or marital disappointment. In such situation, the parents may vent their annoyance on their children. Parents and child guidance that abuse children tend to be socially isolated themselves. Few violent parents belong to any community organizations and most have little contact with friends or relatives. This lack of social involvement deprives abusive parents of support systems that would help them deal better with social or family stress. Moreover, the lack of community contacts makes these parents less likely to change their behaviour to conform to community values and standards.

\section{Recommendation}

Based on the findings discussed above, the following recommendations were made:

1. Parents and child care givers should be further oriented on using better parenting style that will not subject children to any type of child abuse. In addition to this, they should be educated about what can constitute child abuse in their effort to discipline their children.

2. Government and other stakeholders should come up with more social policies that will prevent all forms of child abuse at home and in schools. Such policy should be designed in a way that will be criminal to subject any child to abuse. In addition to this parents and other child care givers should be made aware of the policies.

3. Efforts should be made to educate parents in rural areas on what constitute child abuse. Such orientations should keep the parents informed that activities like hawking, school enrolment delay and early marriage are forms of child abuse. 
INTERNATIONAL JOURNAL OF ACADEMIC RESEARCH IN PSYCHOLOGY

Vol. 2, No. 1, 2015, E-ISSN: 2312-1882 @ 2015 KWP

\section{References}

Adeojo, A. H. (2008). Child abuse, the Nigerian child's experience. Lokoja: Salem Publishers.

Dall'Oglio, A. H. (2004). Saving the children from the prawn of social disadvantages. Hassi: Lake Papers.

Danon, T. U. (1972). Social Psychology. New Jersey: Okltp Books.

Ebigbo, P. O. (1989). Situation analysis of child abuse and neglect in Nigeria: Making use of Nigerian Daily Newspapers. Journal of African Psychology 1, 95-101.

Elebu, S. S. (1990). Child care and economic crisis in Africa. Lagos: Talking Drum.

Federal Republic of Nigeria/FRN. (2006). Reforms in Nigerian Education. Abuja: Government Press.

International Labour Organization/ILO. (2002). Working babies around the world. New York: ILO press.

Kisekka, M. N. (1981). Children in Kaduna State: Nigerian problems and needs. Zaria: Department of Sociology, ABU Zaria Press.

Kwara State Government. (2006). Kwara State compulsory, free universal basic education law: Ilorin: Government Press.

Little, W. R. (1997). Teenage Pregnancy: The parents responsibility: Dude: White Halls.

United Nation Children Emergency Fund/UNICEF, (1996). Children around the World: The Growth and Challenges, Geneva: UNICEF Press.

Welesh, W. F. (2000). Counselling Psychology: New York: Serenity. 